\title{
Czym jest sobór (Sobór Wszechprawosławny) dla Kościoła? Perspektywa prawosławna
}

Rozważania na temat soborowości Kościoła opierają się na nicejsko-konstantynopolitańskim symbolu wiary, w którym wyznajemy: jeden, święty, powszechny i apostolski Kościół. Na pytanie, czym jest sobór z perspektywy prawosławnej, nie da się udzielić jasnej odpowiedzi bez wcześniejszej analizy przymiotów Kościoła, ze szczególnym uwzględnieniem jego powszechności. Wszystkie zatem przymioty Kościoła należy rozpatrywać w kontekście integralności endoeklezjalnej. Jedność, którą arcybiskup Bazyli (Krywoszein) rozumie również jako jedyność Kościoła i opiera się w tym twierdzeniu na eklezjologii św. Bazylego Wielkiego, wynika ze świętości Kościoła ${ }^{1}$. Powszechność i apostolskość natomiast realizują się na zewnątrz, właśnie poprzez Kościół, w Kościele i dla Kościoła, zawsze jako żywego Bogoludzkiego organizmu Jezusa Chrystusa.

Kościół nazywany jest powszechnym, co stanowi polską translację greckiego terminu $\kappa \alpha \theta 0 \lambda$ ıкós. Język cerkiewnosłowiański tłumaczy go jako соборный, co dokładnie wskazuje na „wczechogólność”,

${ }_{1}^{1}$ Zob. Василий (Кривошеин), Богословские труды, Нижний Новгород 2011, s. 552 . 
„wszechogarnięcie” czy też właśnie „powszechność”. Tradycja zachodnia, choć w tłumaczeniu symbolu wiary używa terminu „powszechny", dla określenia swego Kościoła zachowała oryginalne brzmienie greckiego słowa „katolicki”, dodając przedrostek „,rzymsko".

Jednak w sensie stricte eklezjalnym termin „katolickość” domaga się nie tylko analizy translatorskiej, lecz także poszerzonej analizy dogmatycznej. Dla Włodzimierza Łosskiego cecha katolickości odnosi się również do prawosławnej triadologii. Interpretując 34. kanon apostolski ${ }^{3}$, ustanawiający administrację synodalną prowincji metropolitalnych na wzór endotrynitarnych relacji, teolog ten pisał:

„To w świetle dogmatu o Trójcy Świętej najwspanialsza cecha Kościoła cecha katolickości - ukazuje prawdziwy swój sens, ściśle chrześcijański, sens, którego nie można wyrazić za pomocą abstrakcyjnego terminu «powszechność». Bardzo konkretne bowiem znaczenie słowa «katolickość» obejmuje nie tylko jedność, lecz także wielość; wskazuje na zgodność jednego z drugim lub raczej na pewnego rodzaju tożsamość jedności i wielości, która sprawia, że Kościół jest katolicki zarówno jako całość, jak i w każdej ze swych części. Pełnia całości nie jest sumą części, każda część posiada tę samą pełnię, co całość. Cud katolickości objawia w samym życiu strukturę właściwą Trójcy Świętej”".

W podobnym duchu pozostają rozważania metropolity Jeroteusza Vlachosa dostrzegającego katolickość jako przejaw całego Kościoła

${ }^{2}$ Zob. Соборность Церкви, [w:] Иларион (Алфеев), Православие, т. I, Москва 2009, s. 676.

3 „Biskupi każdego narodu znać powinni pierwszego między sobą, za głowę go uważać i nie czynić niczego bez jego decyzji, co by ich władzę przekraczało; czynić zaś wolno każdemu to jedynie, co się odnosi do jego biskupstwa i miejscowości do niego należących. Lecz i pierwszy biskup niech niczego nie czyni bez narady ze wszystkimi, albowiem w ten sposób tylko może być zachowana jednomyślność i wysławiony przez Pana w Świętym Duchu Bóg, Ojciec i Syn i Święty Duch". Kanony Kościoła Prawosławnego w przekładzie polskim, tłum. A. Znosko, t. 1, Warszawa 1978, s. 19.

${ }^{4}$ W. Łosski, Teologia mistyczna Kościoła wschodniego, Warszawa 1986, s. 157. 
w ramach każdego lokalnego Kościoła z zachowaniem jedności i tożsamości wiary, a nade wszystko jej eucharystycznego charakteru. Jako analogię przywołuje on sakrament Eucharystii. Każda cząstka eucharystycznego Chleba zawiera w sobie „całego Chrystusa”. Taka sama rzeczywistość obecna jest w soborowym Kościele. Hierarcha pisze:

„Każdy Kościół lokalny jest całym Kościołem w miniaturze. Oznacza to jednak, że każdy Kościół lokalny, aby być «katolickim», musi przechowy-

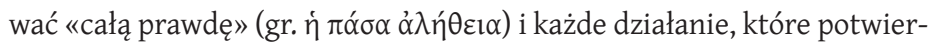

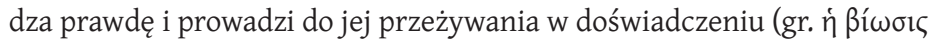
$\tau \tilde{\eta} \varsigma \alpha \dot{\alpha} \lambda \eta \theta \dot{\varepsilon} \alpha \varsigma))^{\prime \prime}$.

W takim wymiarze „soborowość” stanowi jedną z najważniejszych cech Kościoła prawosławnego, określającą jego eklezjalną istotę. Cała wschodnia eklezjologia zachowuje dzięki temu swoją autentyczność - to swoisty barometr Kościoła. Soborowość to również wymiar tajemnicy Kościoła, który doświadcza jej na każdym poziomie życia, w tym również w wydarzeniu soboru jako zgromadzenia ${ }^{6}$. Dla biskupa Atanazego (Gievtitsa) natomiast sobory wyrażają i objawiają istnienie oraz życie Kościoła, są wyrazem eklezjalnej wiary w działaniu. To przejaw również samej Trójcy Świętej, która się „ukościelniła”, aby zbawić upadłego człowieka7.

Różna etiologia zwoływania soborów miała swój wpływ na ich późniejszą recepcję i rangę. Grecka tradycja eklezjalna dokonuje w swojej terminologii szczególnego rozróżnienia pomiędzy soborowością a synodalnością Kościoła. Samo słowo „sobór” oznacza bardziej „synaksę”. W prawosławiu jest nią zgromadzenie, jak również liturgiczne wysławianie Matki Bożej, aniołów i świętych.

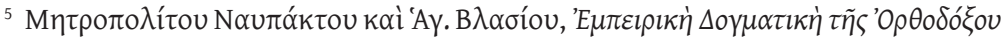

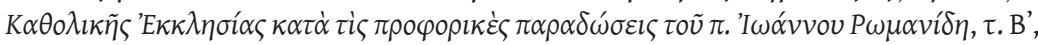

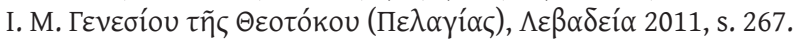

${ }^{6}$ Zob. NSO, s. 29.

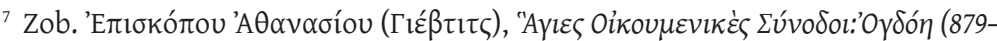

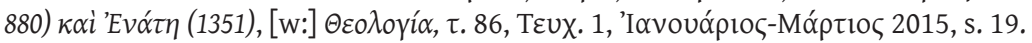


W przypadku Matki Bożej i św. Jana Chrzciciela synaksa dotyczy wielu świąt związanych z ich życiem, obchodzonych dawniej w jednym dniu. Na pamiątkę tego dawnego zwyczaju do dnia dzisiejszego w drugi dzień świąt Bożego Narodzenia obchodzi się synaksę Przenajświętszej Bogurodzicy, a w drugi dzień Chrztu Pańskiego synaksę św. Jana Chrzciciela. W sensie eklezjalnym synaksą jest również „zjazd” bądź „zgromadzenie” zwierzchników lokalnych Kościołów prawosławnych, czy nawet ich przedstawicieli. Termin „synod”, który w literalnym tłumaczeniu oznacza „wspólną droge”" ( $\sigma u v$ - razem, wspólnie, í ó ós - droga), nabiera w tym kontekście szczególnego znaczenia - staje się ważniejszy od soboru. Wiąże się to również z tak ważnym pojęciem „katolickości”.

W odniesieniu do soborów powszechnych język grecki nie posługuje się określeniem „sobór”, ale raczej „synod ekumeniczny”, jak w przypadku przymiotu Kościoła. Zasadnicza różnica kryje się w aspekcie semantycznym obu pojęć. Otóż „,katolickość” wyraża jedność we wspólnocie oraz wspólnotę w jedności. Powszechność zaś jest drogą do katolickości eklezjalnej. Dlatego recepcja prawd wiary wyrażonych w jej obronie przez sobory powszechne miała również, może nawet głównie, charakter soteriologiczny. Ich świadome odrzucenie oznaczało pozostanie $\mathrm{w}$ herezji, ich recepcja natomiast wymagała eklezjalnej świadomości Kościoła, który w swej katolickości, będącej archetypem Świętej Trójcy, nie błądzi i się nie myli. Sobór powszechny nie zbierał się dla ustanawiania prawdy, lecz dla jej obrony i potwierdzenia jej zbawiennego charakteru. To charisma veritatis, czyli dar prawdy, był atrybutem soboru powszechnego. Oto co mówi na ten temat biskup Kallistos Ware:

„Na prawdziwym Soborze Powszechnym biskupi dowiadują się, co jest prawdą, i wtedy ją ogłaszają. Takie ogłoszenie weryfikuje się jego akceptacją ze strony całego świata chrześcijańskiego, która [akceptacja], z reguły, nie posiada bezpośredniego wyrażenia, lecz po prostu żyje".

${ }^{8}$ Суt. zа: Д. М. Ферберн, Инными гъазами... Взгляд евангельского христианина на Восточное Православие, Москва 2002, s. 15. 
Biskupi nie zbierali się więc po to, aby na nowo ustanowić prawdę, lecz aby wysłuchać, jaka jest prawda, a zatem ją ogłosić.

W klasyfikacji soborów najwyższy rangą jest sobór powszechny, następnie lokalny. Znane były bardzo ważne skądinąd sobory Endimusa, charakteryzujące się nagłością zwołania. Uczestniczyli w nich ci hierarchowie, którzy w danym momencie znajdowali się w Konstantynopolu lub nieopodal i mogli na nie przybyć. Dzisiaj sobory otrzymały miano Wielkich i Wszechdoskonałych Synodów

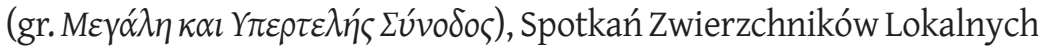
Kościołów Prawosławnych (gr. Al $\Sigma v v \alpha ́ \xi \varepsilon l \varsigma \tau \omega v ~ \Pi \rho \circ \kappa \alpha \theta \eta \mu \varepsilon ́ v \omega v \tau \omega v$

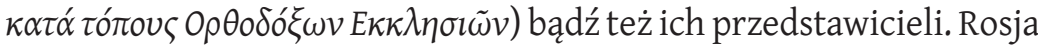
wprowadziła pojęcie „arcypasterskiego soboru” i „lokalnego soboru", na którym wybiera się patriarchę. W innych Kościołach lokal-

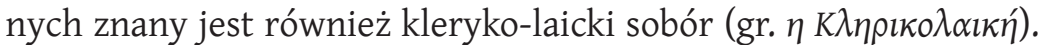
Każdy z tych soborów bądź synodów zajmował się sprawami Kościoła, ale tylko sobór powszechny zajmował się błędami w wierze - herezjami, co oznacza, że rangę powszechności, a więc i ekumeniczności, nadawał takiemu soborowi kolejny sobór powszechny potwierdzający naukę poprzedzających go soborów powszechnych. Taka recepcja w sensie technicznym oznacza przyjęcie, tj. zgodę ze strony ludu, określonej decyzji soborowej lub eklezjalnej. W szerszym znaczeniu termin ten oznacza cały proces, dzięki któremu każde pokolenie przyjmuje Boże Objawienie wynikające z Pisma Świętego i Świętej Tradycji9. Decyzje soborów lokalnych natomiast można było zmieniać postanowieniami innych soborów i synodów, co mogło głównie wynikać z ich czasowej dezaktualizacji.

Dla prawosławia soborowość Kościoła stanowi jego zasadniczy przejaw zewnętrzny i wewnętrzny, który Kościół wyraża nie tylko poprzez sprawowanie wokół biskupa liturgii świętej, lecz również poprzez tzw. tożsamość soborową. Rozpoczyna się ona na poziomie parafialnym poprzez współdziałanie proboszcza i rady, następnie diecezjalnym, gdzie wyrażają ją konkretne organy doradcze,

\footnotetext{
${ }_{9}$ Zob. NSO, s. 29.
} 
następnie lokalnym poprzez zebranie w ramach soboru czy synodu wszystkich bądź wybranych ku temu biskupów danego lokalnego Kościoła prawosławnego. Na przestrzeni wieków w tradycji greckiej ukształtowała się praktyka zwoływania małych i wielkich synodów lokalnych. W starożytnych patriarchatach istnieje zwyczaj zwoływania synodów składających się z ograniczonej liczby biskupów oraz pełnych synodów, na które przybywają wszyscy należący do danego Kościoła biskupi. W tradycji Patriarchatu Ekumenicznego taki synod lub synaksa odbywa się raz w roku, najczęściej 1 września, a więc w dniu rozpoczęcia nowego roku liturgicznego. W Kościele greckim natomiast raz w miesiącu zbiera się tzw. stały synod (gr. $\dot{\eta} \Delta \imath \alpha \rho \kappa \eta ่ \varsigma$

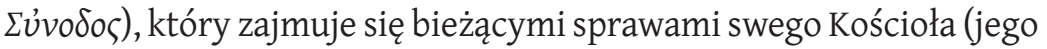
członkowie w liczbie trzynastu, nie licząc zwierzchnika, zmieniają się rotacyjnie po upływie roku liturgicznego). Pozbawiony on jest jednak prawa dokonania wyboru bądź zdymisjonowania biskupa. Dla tej czynności zbiera się wówczas synod, który potocznie określa się mianem „hierarchia”. W Patriarchacie Jerozolimskim w skład synodu wchodzą również mnisi kapłani. O przynależności do synodu decyduje tam przynależność do bractwa Grobu Pańskiego. W mniejszych liczebnie Kościołach zazwyczaj wszyscy biskupi stają się „z urzędu” członkami lokalnych synodów, a czasami właśnie z tego powodu, że uczestniczą w nich wszyscy, synody nazywa się soborami. Taka sytuacja ma miejsce chociażby w Polskim Autokefalicznym Kościele Prawosławnym, z tym że biskupi wikariusze (tradycja wschodnia nie zna pojęcia „biskupa pomocniczego” czy też „sufragana”), zgodnie z jego statutem, nie są kandydatami w przypadku wyboru zwierzchnika Kościoła.

Rosyjski Kościół prawosławny prezentuje jeszcze inny model synodalnego zarządzania. Bieżącymi sprawami, w tym powoływaniem i odwoływaniem biskupów, zajmuje się Święty Synod, w którego skład wchodzą poza patriarchą stali członkowie oraz dobierani na sesję letnią i zimową poszczególni biskupi. Doradczym ciałem synodu jest również Wyższa Rada Kościelna, której członkowie kierują poszczególnymi sektorami życia rosyjskiego Kościoła 
prawosławnego. Poza tym zbiera się również sobór biskupów (arcypasterski sobór), w którym udział biorą wszyscy biskupi oraz lokalny sobór rosyjskiego Kościoła prawosławnego z udziałem duchownych i świeckich desygnowanych do niego po równo z każdej diecezji. Najczęściej wiąże się on również z wyborem patriarchy. Na uwagę zasługuje obecna w Kościele rosyjskim praktyka powoływania tzw. międzysoborowych komitetów (ros. межксоборное присутствие), które mają za zadanie opracowywanie projektów dokumentów soborowych, aby dzięki ich późniejszej publikacji i sondażom opinii publicznej względem proponowanych w nich treści trafiały na sobór jako ogólnie przyjęte.

Na płaszczyźnie soborowości Kościoła prawosławnego kluczową rolę odgrywają również liturgiczne relacje pomiędzy zwierzchnikami lokalnych Kościołów prawosławnych, którzy legitymują się spośród wszystkich innych biskupów prawem i bezwzględnym obowiązkiem wspominania się nawzajem podczas każdej liturgii świętej, nawet tej najbardziej nieoficjalnej, sprawowanej w domowej kaplicy. Na domiar tego, to wspomnienie występuje podczas każdej liturgii kilka razy. Zerwanie łączności eucharystycznej polega właśnie na przerwaniu liturgicznego wspominania i odwrotnie - jej przywrócenie dokonuje się poprzez ponowne wspomnienie razem z innymi i wspólne sprawowanie liturgii. Ten symboliczny zwyczaj jest głęboko zakorzeniony w dogmatycznym nauczaniu o Kościele i jego soborowym charakterze.

W tym kontekście warto pochylić się nad nowym modelem wyrażania synodalnego wymiaru Kościoła, którym stały się zgromadzenia (synaksy) zwierzchników autokefalicznych Kościołów prawosławnych, a więc w istocie sobory. Za czasów kierowania Patriarchatem Ekumenicznym przez patriarchę Bartłomieja odbyło się ich już kilka, przy czym z dużą częstotliwością oraz intensyfikacją prac. Dotyczyły one nie tylko wszechprawosławnego soboru, ale również problemu schizmy w Bułgarii (1998), dymisji patriarchy Jerozolimy (2005) czy uroczystości jubileuszowych. Przyjęto zasadę, że decyzje na takich spotkaniach będą podejmowane na zasadzie 
konsensusu, co najlepiej wyraża soborowego ducha prawosławia. To właśnie dlatego przebiegają one nieraz w trudnej atmosferze konstruktywnej dyskusji.

$\mathrm{Na}$ ostatnim takim zgromadzeniu-synaksie, 22 stycznia 2016 roku w Genewie, patriarcha ekumeniczny Bartłomiej powiedział między innymi:

„Rzeczywiście, każde nasze wspólne zgromadzenie (synaxis) - tych, którym łaska i miłosierdzie Boże powierzyły prowadzenie Świętego i Bożego Kościoła - jest uświęcone. Jednak obecne nasze zgromadzenie nabiera wyjątkowo tego charakteru, ponieważ wiąże się z fundamentalną zasadą kościelną soborowości Kościoła, która ma jako główny cel przygotowanie mającego się zebrać, z Bożą pomocą, Świętego i Wielkiego Synodu naszego Najświętszego Prawosławnego Kościoła. Zgromadziliśmy się zatem tutaj, aby rzeczywiście spełnić święty dług i właśnie dlatego mamy potrzebę oświecenia od Parakleta, ale też potrzeba nam, i to ze strony każdego z nas, dobrej woli, dalekiej od jakichkolwiek innych pobudek, abyśmy przyczynili się poprzez nasze decyzje do zwołania już dawno zapowiedzianego przez nas Świętego i Wielkiego Synodu"10.

Wypowiedź patriarchy rozróżnia zatem mający się odbyć sobór od synaksy zwierzchników. Ta ostatnia dokonuje się z inicjatywy patriarchy ekumenicznego bądź na wniosek jednego ze zwierzchników, który jest do niego składany. Agenda synaksy nie wymaga konsensusu i może mieć różną etiologię. W przypadku Soboru Wszechprawosławnego agenda obrad została jasno określona, a jej rozszerzenie lub ograniczenie wymaga zgody wszystkich. Na synaksie w styczniu 2016 roku przyjęto jeden z ważniejszych dla synodalnego charakteru soboru dokument - Regulamin zwołania i obrad Świętego i Wielkiego Soboru Kościoła prawosławnego ${ }^{11}$.

${ }^{10} \mathrm{Z}$ prywatnego archiwum autora, uczestnika wspomnianego zgromadzenia.

${ }^{11}$ Zob. Règlement d'organisation et de fonctionnement du Saint et Grand Concile de l'Église orthodoxe (Chambésy, 27 janvier 2016), https://mospat.ru/fr/2016/01/28/ news127391/ (28.01.2016). 
Pierwszy paragraf regulaminu definiuje dokładnie, czym w świadomości prawosławnej powinien być ten sobór. $\mathrm{W}$ dokumencie tym czytamy:

„Święty i Wielki Sobór (Synod), z łaski Świętej Trójcy, stanowi autentyczne wyrażenie (przejaw) kanonicznej tradycji i diachronicznego działania kościelnego względem funkcjonowania soborowego systemu w Jednym, Świętym, Powszechnym i Apostolskim Kościele, i zwoływany jest przez Jego Świątobliwość Patriarchę Ekumenicznego, za zgodą Wielce Błogosławionych Zwierzchników wszystkich i przez wszystkich uznawanych lokalnych Kościołów autokefalicznych. W jego skład wchodzą wyznaczeni członkowie ich delegacji” ${ }^{12}$.

Definicja ta w pełni odpowiada prawosławnej nauce o soborowości Kościoła. Warto w tym miejscu podkreślić, że obawy związane ze zwołaniem Świętego i Wielkiego Soboru nie dotyczą jego istoty, znaczenia w życiu Kościoła prawosławnego, lecz bardziej odnoszą się do jego agendy, która mogłaby, zdaniem wielu, być przyjęta na zwykłej synaksie zwierzchników i ich legatów. Co jest zatem celem przyszłego soboru? Otóż jego zasadniczym celem jest świadectwo jedności prawosławia, które poruszy przy okazji najbardziej nabrzmiałe zagadnienia natury kościelno-administracyjnej (co do tych dokumentów nie ma większych zastrzeżeń), społeczno-obyczajowej i geopolitycznej.

W odniesieniu do dwóch ostatnich zagadnień pojawiają się różne opinie, wynikające: po pierwsze, z odmienności uwarunkowań społeczno-politycznych, w jakich funkcjonują poszczególne Kościoły lokalne; po drugie, z gwałtowanej zmienności problematyki życia społecznego; a po trzecie, z uwagi na ich rzekomo „niesoborowy” status, ponieważ problemy te, tak czy inaczej, rozwiązywane są w perspektywie duszpasterskiej troski w ramach każdego Kościoła lokalnego z uwzględnieniem jego specyfiki i uwarunkowań, w jakich

${ }^{12}$ Tłumaczenie własne na język polski; maszynopis w prywatnym archiwum autora. 
żyje. Świadectwo jedności jest i pozostaje jednak wciąż zasadniczym powodem i celem zwołania wszechprawosławnego soboru. Poza przyjętą agendą soborową zostanie przygotowane specjalne orędzie soborowe. W tym celu każdy Kościół lokalny desygnuje jednego hierarchę do Specjalnej Komisji Soborowej, która spotka się na Krecie w dniach 9-16 czerwca br., aby przygotować projekt orędzia, z uwzględnieniem postulatów zwierzchników wszystkich Kościołów lokalnych. W dniach 17-18 czerwca br. odbędzie się nadzwyczajna synaksa zwierzchników autokefalicznych Kościołów prawosławnych, którzy przyjmą tekst wspomnianego orędzia.

W prawosławnej perspektywie sami zwierzchnicy nie stanowią o swoich Kościołach, ale jako ich wybrani przywódcy wyrażają wolę synodów i soborów lokalnych ich Kościołów, a także duchowieństwa, mnichów i wiernych. Dlatego proces złożenia przez zwierzchnika Kościoła podpisu pod dokumentem soborowym wymagał i nadal wymaga pogłębionej analizy wewnętrznej i wspólnego stanowiska.

Spośród wielu paragrafów Regulaminu Soboru Wszechprawosławnego dodatkowego komentarza wymagają niektóre, jak chociażby etiologia określenia liczby uczestników soboru. Historia soborów powszechnych pokazuje praktykę uczestnictwa wszystkich biskupów świata, chyba że obecność uniemożliwia choroba lub sędziwy wiek. Znane są przypadki absencji nawet papieża bądź patriarchów wschodnich. Byli oni jednak reprezentowani na soborach przez uprawnionych i w pełni upoważnionych do tego legatów. Obecność wszystkich biskupów świata na Świętym i Wielkim Soborze Kościoła prawosławnego była niejednokrotnie brana pod uwagę. Na synaksie zwierzchników w marcu 2014 roku jednogłośnie zdecydowano, że byłoby to technicznie trudne. Każdy biskup jednak nadal dysponuje prawem akceptacji bądź też dezaprobaty przyjmowanych dokumentów, zarówno w procesie przedsoborowym, jak i soborowym. Przełomowym punktem synaksy była jednak wspólna decyzja, że bez względu na przebieg debaty w danym Kościele lokalnym, na Świętym i Wielkim Soborze każdy Kościół lokalny otrzymuje 
jeden głos. Taka decyzja wynikała między innymi z ogromnej dysproporcji liczby biskupów w poszczególnych Kościołach. Ponieważ głos należy do Kościoła, a nie do poszczególnych biskupów, liczba hierarchów delegowanych na sobór nie ma większego znaczenia, aczkolwiek musi być ona symboliczna i pokaźna. Początkowo debatowano nad możliwością uczestnictwa, poza zwierzchnikiem, dwunastu biskupów z każdego Kościoła jako symbolu dwunastu apostołów. Następnie przyjmowano już techniczną liczbę dwudziestu, a na wniosek zwierzchnika Kościoła albańskiego, najstarszego obecnie wiekiem, przyjęto liczbę dwudziestu czterech biskupów jako liczbę, o której jest mowa w Objawieniu św. Jana. Kościoły, które nie dysponują taką liczbą hierarchów, a więc Polski, Albanii oraz Czech i Słowacji, wystąpią w dowolnej dla siebie liczbie. Dodatkowo każdy Kościół może mieć po sześciu doradców z kręgu duchowieństwa, mnichów i osób świeckich, a także po trzech wolontariuszy. Ostatnie dwie grupy nie biorą udziału w dyskusji i głosowaniu. Ponadto każdy Kościół ma swoich dwóch konsultantów - biskupów, którzy zasiadają bezpośrednio za swoim zwierzchnikiem, co wynika z racji praktycznych i z zasad zajmowania miejsc na soborze przez zwierzchników poszczególnych Kościołów. Tutaj wzorowano się na ikonach soborów I tysiąclecia. Każdy Kościół ma również jednego przedstawiciela w randze biskupa w Wszechprawosławnym Sekretariacie Soboru oraz przedstawiciela mediów.

Warto odnieść się także do paragrafu ósmego regulaminu, który wspomina o możliwości pisemnego zgłaszania i nanoszenia poprawek do dotychczas przyjętych i podpisanych projektów tekstów soborowych. Należy wyjaśnić, że taka możliwość istnieje, jednak w przypadku braku konsensusu odnośnie do ich przyjęcia tekstem soborowym pozostaje ostatnia wersja dokumentu podpisana wcześniej przez wszystkich na przedsoborowych konferencjach bądź zgromadzeniach zwierzchników. Istnieje również możliwość zaprotokołowania faktu nieprzyjęcia poprawek przez dany Kościół bądź poszczególnych członków konkretnej delegacji. Dlatego warto w tym miejscu zacytować drugi i trzeci punkt dwunastego 
paragrafu regulaminu, aby pokazać jego prawdziwie soborowy charakter. W punkcie drugim czytamy:

„Sytuacja, gdy na Soborze głosuje Kościół, a nie członek delegacji, nie wyklucza możliwości, że jeden bądź też kilku członków delegacji tego czy innego Kościoła autokefalicznego zajmą negatywne stanowisko w kwestii naniesienia poprawek lub nawet tekstu w ogóle. Fakt braku zgody odnotowuje się w protokole".

Natomiast w kolejnym, trzecim punkcie zapisano:

„Ocena takiej dezaprobaty stanowi wewnętrzną sprawę tego Kościoła autokefalicznego, do którego należą ci biskupi. Kościół może wtedy taką kwestię przegłosować, korzystając z przywileju wewnętrznej większości głosów, co zgłasza na plenum jego zwierzchnik. Dlatego też należy zagwarantować takiemu Kościołowi niezbędne miejsce i czas dla dyskusji w tej sprawie wewnątrz własnej delegacji” ${ }^{13}$.

Te dwa zapisy wskazują na bardzo istotną kwestię dla zasady soborowości w Kościele prawosławnym. Przyznanie jednego głosu jednemu Kościołowi na mającym się odbyć Świętym i Wielkim Soborze nie oznacza wymuszenia konsensusu w ramach własnej delegacji. Każdy biskup legitymuje się tym samym prawem kanonicznym i kościelnym. Gdyby ten zapis nie znalazł się w regulaminie przyszłego soboru, wówczas można byłoby spekulować o braku prawa dezaprobaty względem niektórych fragmentów bądź poprawek wnoszonych do soborowych dokumentów.

Reasumując, Święty i Wielki Sobór Wszechprawosławny jest jednocześnie szansą i wyzwaniem dla Kościoła prawosławnego. Szansą ponieważ Kościół głośniej niż zwykle będzie mógł powiedzieć o swojej niezmiennej tożsamości, wyzwaniem natomiast, ponieważ od wielu wieków nie było soboru w tak szerokim wymiarze kościelnym i organizacyjnym. Recepcja soboru zawsze była wynikiem działania

${ }^{13}$ Tłumaczenie własne; maszynopis w prywatnym archiwum autora. 
łaski Ducha Świętego, a zatem należy mieć nadzieję, że odbędzie się on zgodnie z wolą Bożą.

\section{Bibliografia}

Иларион (Алфеев), Соборность Церкви, [w:] Иларион (Алфеев), Православие, т. I, Москва 2009, s. 676-685.

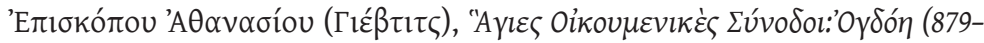

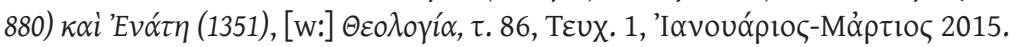

Ферберн Д. М., Инными гьазами... Взгляд евангельского христианина на Восточное Православие, Москва 2002.

Kałużny T., Nowy sobór ogólnoprawosławny. Natura, historia przygotowań, tematyka, Kraków 2008 [=NSO].

Kanony Kościoła Prawosławnego w przekładzie polskim, tłum. A. Znosko, t. 1, Warszawa 1978.

Łosski W., Teologia mistyczna Kościoła wschodniego, Warszawa 1986.

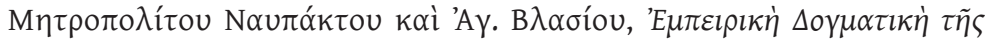

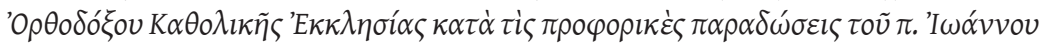

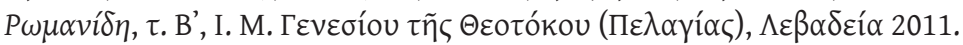

Règlement d'organisation et de fonctionnement du Saint et Grand Concile de l'église orthodoxe (Chambésy, 27 janvier 2016), https://mospat.ru/fr/2016/01/28/ news127391/ (28.01.2016).

Василий (Кривошеин), Богословские труды, Нижний Новгород 2011.

\section{What is a Council (Pan-Orthodox Council) to the Church? The Orthodox Perspective}

SUMMARY

The concepts of "conciliarity" and "the council" are essential for the Orthodox Church. They express not only the principles of its functioning in ecclesial and administrative sense, but they are also deeply rooted in dogmatic theology. The council in fact reflects the will of God and the action of grace of the Holy Spirit. In the context of the upcoming Great Pan-Orthodox Council the reflection on the conciliar spirit of the Orthodox Church should help to 
understand both the reasons for which it is convened, as well as the expectations that are associated with it. Council's agenda is focused on resolving some issues of the canonical nature, as well as the challenges of the modern world. Council becomes both an opportunity and a great challenge, facing the fact that it takes place after many centuries from the last council.

KEYWORDS: conciliarity, universality, catholicity, council, synod, synaxis, council by-laws

SŁOWA KLUCZOWE: soborowość, powszechność, katolickość, sobór, synod, synaksa, regulamin soboru 